\title{
The Theoretical Logic and Implementation Path of Technology Finance to Improve the Profitability of Commercial Banks
}

\author{
Yizhuo Fang \\ School of Economics, Xinjiang University of Finance and Economics, Urumqi, China \\ Email: FangYizhuo@163.com
}

How to cite this paper: Fang, Y. Z. (2020). The Theoretical Logic and Implementation Path of Technology Finance to Improve the Profitability of Commercial Banks. Open Journal of Social Sciences, 8, 336-344. https://doi.org/10.4236/jss.2020.810022

Received: September 17, 2020

Accepted: October 26, 2020

Published: October 29, 2020

Copyright $\odot 2020$ by author(s) and Scientific Research Publishing Inc. This work is licensed under the Creative Commons Attribution International License (CC BY 4.0).

http://creativecommons.org/licenses/by/4.0/

\begin{abstract}
Science and technology empowering the financial exhibition industry is an important measure and a useful attempt to realize the transformation and development of the financial sector. In the business model of commercial banks, the application of technology financial tools, methods and models can play a positive role in three aspects of customer group marketing, customer service and internal operations, including the realization of high-speed retail customer groups and institutional customer groups. Growth, ensures efficient services for retail customers and institutional customers, and promotes the deep integration of operations and business links. Based on this, commercial banks should clarify the development path of technology finance, strengthen the application efficiency of technology finance, accelerate the talent pool of technology finance, and ensure that the technology finance strategy can be efficiently implemented, effectively empowered, and sustained, thereby enhancing the core competition of commercial banks. Power and ultimately improve the profitability of commercial banks.
\end{abstract}

\section{Keywords}

Technology Finance, Commercial Banks, Profitability, Cost Reduction and Efficiency Enhancement, Technology Empowerment

\section{Introduction}

Since the financial crisis broke out in the United States in 2008, the recovery of the world economy has been struggling, and my country's economy has also entered a new normal development stage. Under the new normal of the economy, my country's economic structure continues to upgrade, economic growth is gradually shifted, and economic drivers are rapidly shifted. This has a great impact on all industries in my country, and the financial industry is no exception. 
As we all know, commercial banks are important market players in the financial system, related to the stability of a country's financial system, and are the main source of corporate financing, especially in China where indirect financing is the main financing method. Commercial banks are in the financial system. The status in China is particularly important (You, 2020). At the same time, with the continuous deepening of my country's market economy reform and the continuous acceleration of the opening of the capital market, the market competition of my country's commercial banks has undergone great changes, with the increase of competition subjects, the increase of competition pressure and the strengthening of competition trends. To a certain extent, this puts forward higher requirements on the operating capabilities of our commercial banks (Wu, 2020).

However, the current business model, business philosophy, business status, and business characteristics of my country's commercial banks cannot meet the current financial market competition needs. At the same time, the business model of commercial banks is also difficult to meet the growing business needs of customers. In this context, the profitability of commercial banks is greatly suppressed, which will eventually affect the sustainable development of commercial banks (Wang et al., 2020). In view of this, my country's major commercial banks are seeking to reform their business models and implement reform measures for transformation and development in order to improve the profitability of commercial banks. Technology and financial strategies are commonly adopted important measures. In view of this, this article takes the conceptual connotation and basic characteristics of technology finance as the breakthrough point, and focuses on exploring the economic logic of technology finance to promote the profitability of commercial banks, and on this basis analyzes the profitability of commercial banks from the perspective of technology finance. The promotion strategy has certain theoretical value and practical significance (Lu, 2020).

\section{The Economic Logic of Technology Finance to Promote the Profitability of Commercial Banks}

In order to better explore the specific measures for commercial banks to develop technology finance strategies, the article first analyzes the economic logic of financial technology to promote the profitability of commercial banks, with a view to clarifying the role and mechanism of technology finance in promoting profitability of commercial banks. This article analyzes the promotion effect of technology finance on the profitability of commercial banks from three levels of marketing, service and operation. The specific analysis is as follows.

\subsection{Technology Finance Empowers the Marketing System of Commercial Banks to Achieve Rapid Growth of Retail Customers and Institutional Customers}

Technology finance empowers the marketing system of commercial banks. This is the basic logic for technology finance to promote the profitability of commer- 
cial banks. The path of influence is: commercial banks realize the rapid growth of retail customers and institutional customers through the application of technology financial tools to ensure commercial. The bank's customer base continued to grow, laying a solid customer base for the rapid development of the business (Zhang, 2017).

On the one hand, at the retail customer level, commercial banks can use financial technology financial tools to achieve the following goals: First, through the application of big data, cloud computing, and intelligent technology, commercial banks can effectively carry out precise marketing to target customer groups. Maximize the number and quality of new retail customers, thereby laying a solid customer base for the transformation and development of commercial banks' retail business; second, commercial banks can be targeted by analyzing the basic characteristics and demand preferences of new customer groups The launch of corresponding financial services and products to achieve precise, targeted, and efficient marketing to target customer groups, thereby continuously attracting customers' asset transfer; third, due to the support of technological financial tools, commercial banks have integrated retail customer groups Accurate monitoring, calculation and analysis of indicators such as cost, overall output, new process, and new efficiency provide good practical support for commercial banks to optimize their marketing systems, and ultimately help commercial banks to optimize their marketing systems. , Strengthen the customer acquisition capabilities of commercial banks.

On the other hand, at the institutional customer level, commercial banks can effectively dig out the business needs and business pain points of corporate customers and institutional customers through the analysis of massive amounts of data. For a long time, my country's corporate financing methods have mainly been indirect financing, so corporate customers, institutional customers, and high-end customers are important target customers of commercial banks. From a practical operation point of view, commercial banks can take advantage of the information acquisition advantages of technological financial tools to accelerate the innovation of their own financial products and the improvement of financial services, and thereby lay a professional foundation for better meeting the business needs of institutional customers, corporate customers, and high-end customers basis. More importantly, with the continuous development of financial innovation, more and more financial business development requires the integration of science and technology. For example, customers have many customized requirements for the APP platform of commercial banks, and they have clear, high-precision, low-latency personalized requirements for commercial bank business system optimization (Yu, 2017).

\subsection{Technology Finance Reshapes the Service Framework of Commercial Banks to Ensure Efficient Services for Retail Customers and Institutional Customers}

Technology finance reshapes the service framework of commercial banks. This is 
the key logic for technology finance to promote the profitability of commercial banks. The path of influence is: commercial banks ensure efficient services for retail customers and institutional customers through the application of technology financial tools, and enhance customer loyalty degree. The improvement of the service of technology finance to commercial banks is mainly reflected in two levels:

First of all, the application of technological financial tools by commercial banks can improve the effectiveness of commercial bank employees in serving customers, improve work efficiency, and reduce commercial bank service costs. Especially for the majority of retail customers, it is difficult to achieve the benefits to retail customers by manpower alone. With the comprehensive coverage of technology and financial tools, one-to-many, high-performance, wide-coverage, and highly-labeled services can be realized only by relying on the technical advantages of technology financial tools. At present, judging from the practical effects of China Merchants Bank, Industrial and Commercial Bank, and Ping An Bank, accelerating the R \& D investment and application of technology financial tools can effectively improve the service stickiness and service efficiency of retail customers.

Second, the application of technological financial tools can enhance the service capabilities of commercial bank employees, enrich the service content of commercial bank employees, and improve the efficiency and quality of commercial bank employees in serving customers, especially for corporate customers, institutional customers, and high-net-worth customers. High professionalism is an important foundation and core guarantee for commercial bank employees to smoothly serve these customers. However, for the employees of many commercial banks, they have insufficient work experience, lack of work ability, and poor personal resource endowments, so they need efficient technology and financial tools to help and empower them (Chen \& Sun, 2019).

Furthermore, commercial banks can effectively solve customer service performance evaluation problems that have been difficult for commercial banks to solve for a long time by applying scientific and technological financial tools. As we all know, the financial industry is a productive service industry. It is difficult for employees to accurately quantify the service work of customers, and it is impossible to effectively evaluate the service effectiveness of employees in a timely, accurate and objective manner. With the application and embedding of technological financial tools, through the application of intelligent data systems, commercial banks can further subdivide financial service work that is difficult to quantify, so that service work can be measured, service performance can be counted, and service level can be measured. Evaluation Quantitative evaluation of customer services can effectively help commercial bank management find loopholes in the service system, thereby improving the deficiencies of the service system in a targeted manner, thereby comprehensively improving the service level of commercial banks and enhancing the profitability of commercial banks. 


\subsection{Technological Finance Reforms the Operating Mechanism of Commercial Banks and Promotes the Deep Integration of Operation and Business Links}

Technological finance innovates the operating mechanism of commercial banks. This is one of the important logics for technological finance to promote the profitability of commercial banks. The path of influence is: commercial banks promote the deep integration of operation and business links through the application of technological financial tools to enhance commercial banks the actual effectiveness of business management (Zhang, 2013).

First, commercial banks can effectively improve the efficiency of commercial banks' internal operations through the application of technological financial tools. For example, paperless operations, electronic operation management systems, smart APP platforms, etc., these technological financial tools can greatly improve the operational efficiency of commercial banks' internal business and daily management, thereby reducing the operating costs of commercial banks and improving commercial banks The internal management efficiency of commercial banks has effectively promoted the implementation of cost reduction and efficiency enhancement of commercial banks, and ultimately promoted the improvement of commercial banks' profitability.

Second, operating risk is an important business feature of commercial banks. Through the application of scientific and technological financial tools, commercial banks can fully grasp the internal operating data and conditions of commercial banks, basic data collection, analysis and mining, commercial banks can explore from the level of business development the shortcomings in the operation and management of commercial banks effectively enhance the risk prevention and control capabilities of commercial banks. For example, whether there is poor collaboration between front and back office employees, and whether there is illegal marketing (Zhang, 2020).

\section{Implementation Path of Commercial Banks' Profitability from the Perspective of Technology Finance}

Based on the economic logic analysis of the advancement of scientific and technological finance in promoting the profitability of commercial banks, combined with the current practical experience of domestic and foreign commercial banks in implementing scientific and technological finance strategies. This article explores the implementation path of commercial banks' profitability from the perspective of technology finance. The conclusion shows: commercial banks should develop technology finance strategies. They should clarify the development plan of technology finance, strengthen the efficiency of technology finance, and accelerate the talent pool of technology finance. The realization of the technology and financial strategy has sufficient resource guarantee, prominent application value, and sustainable intellectual support, which truly contributes to the improvement of commercial banks' profitability. 


\subsection{Clarify the Development Plan of Technology Finance, and Realize the Efficient Matching of Top-Level Design and Execution Plan}

A clear development plan for technology finance is the basis and prerequisite for commercial banks to implement technology finance strategies. Through the formulation of science and technology finance plans, it is possible to effectively clarify the scale of human, financial and material resources that commercial banks should invest in developing science and technology finance, and to further ensure that various resource supports are in place by constructing systems. But two aspects must be paid attention to:

First, the top-level design plan and specific implementation plan of commercial banks for the development of science and technology finance must maintain a high degree of compatibility in terms of direction, principles, and standards, so as to maximize the consensus on the development of commercial banks' science and technology finance strategy and truly reduce the implementation of science and technology finance strategies. Resistance to accelerate the popularization of the application and model of commercial banks' scientific and technological financial tools.

Second, the top-level design of the technology finance strategy must specify the specific business objectives of the technology finance strategy. This goal must bring about cost reduction, efficiency increase, intensive, and quality improvement effects on the main business of commercial banks, and it must be able to truly promote the rapid, steady and sustainable development of the main business of commercial banks, and promote various businesses of commercial banks. Achieving leapfrog development can ultimately effectively improve the profitability of commercial banks (Wang, 2020).

In addition, the top-level design plan of technology finance must be executable to ensure the smooth implementation of the execution plan.

\subsection{Strengthen the Application Efficiency of Science and Technology Finance, and Focus on the In-Depth Integration of Science and Technology and Financial Business}

The implementation of the commercial bank's technology finance strategy must focus on the efficient empowerment of technology for financial services. Therefore, strengthening the application efficiency of technology finance has become the key to the smooth implementation of the commercial bank's technology finance strategy. Its core goal is to promote the depth of science and technology and financial services. Fit.

First of all, debt business is the foundation for the development of various businesses of commercial banks. The development of technology finance strategy should further improve the operational efficiency of commercial banks' debt business and continuously improve the competitiveness of commercial banks' debt business. At the same time, by improving the level of customer service, improving the functions of various system platforms of commercial banks, and op- 
timizing the effectiveness of various customer marketing and service activities of commercial banks, the ability of commercial banks to absorb deposits is comprehensively improved, laying a foundation for the improvement of commercial banks' profitability (Wang, 2017).

Secondly, asset business is the main business for commercial banks to obtain income, including cash asset business, credit business, investment business, and discount business. Through the application of scientific and technological financial tools, commercial banks can empower commercial bank asset businesses in three aspects: First, more accurately identify target customers. Through the collection, analysis and mining of massive data, commercial banks can effectively judge customers. In turn, commercial banks can efficiently match loan products that meet the needs of their customers. Second, through the application of financial means, scientific and technological financial means, the cumbersome review procedures of commercial banks' asset businesses can be greatly reduced. Enhance the convenience of loan services and better help commercial banks acquire customers; third, through the provision of scientific and technological financial technology tools, it can efficiently, real-time, accurately and reliably carry out dynamic monitoring and early warning of commercial bank asset business risk points, effectively Prevent the occurrence of non-performing loan risks of commercial banks and reduce the losses of commercial banks.

Furthermore, the intermediary business is an important measure for commercial banks to improve their income structure and achieve transformation and development. The implementation of technology finance strategy, on the one hand, can promote commercial banks to implement intermediary business innovation, thereby enhancing the ability of commercial banks to develop intermediary business; on the other hand, through the application of technology finance strategy, it can effectively reduce the risks that intermediary business brings to commercial banks. , And then increase the willingness of commercial banks to develop intermediary business, thereby enhancing the enthusiasm of commercial bank employees to develop intermediary business, and ultimately enhance the profitability of commercial banks.

\subsection{Accelerate the Talent Pool of Technology and Finance to Ensure the Seamless Connection between Technology Research and Development and Business Applications}

In the era of knowledge economy, talent is the primary productive force. Commercial banks' development of technology finance strategy must be based on a sufficient reserve of technology finance talents. Therefore, commercial banks must focus on the excavation and cultivation of scientific and technological financial talents to ensure that scientific and technological financial technology $R \& D$ and the application of scientific and technological financial tools in financial services can be seamlessly connected. Judging from the practical experience of domestic and foreign commercial banks developing technology finance strategies, commercial banks have taken two measures to accelerate the reserve of 
scientific and technological talents (Lai, 2018).

On the one hand, commercial banks should focus on the excavation, selection and cultivation of internal financial technology talents. Since the internal talents of commercial banks are familiar with financial business, they can better grasp the application direction and work focus of science and technology finance, thereby improving the operability and execution of science and technology finance strategy, and enhancing the empowerment of science and technology finance strategy on financial business effect

On the other hand, commercial banks should pay attention to the introduction of high-quality technology and financial talents from outside, especially the introduction of interdisciplinary and compound talents. Commercial banks should continuously optimize the age structure and educational background structure of the technology and financial talents to truly build a team of high-quality talents who understand finance, know technology, and are good at risk prevention and control provide intellectual guarantee for improving the profitability of commercial banks.

\section{The Research Conclusion}

All in all, the implementation of the technology and financial strategy is a necessary measure and a useful attempt for commercial banks to achieve their transformational development goals in the era of intelligence, information and digitalization. Facing the increasingly open financial market, continuously developing customer demand, and intensifying market competition, the use of iterative science and technology to help business development is bound to be an important means and strategy for commercial banks to enhance their core competitiveness. From the logic of economics, the beneficial effects of technology finance on commercial banks mainly include three aspects: first, to improve the marketing efficiency of commercial banks, which is conducive to increasing the input-output ratio of commercial banks at the marketing level; second, to improve the customer service experience of commercial banks truly enhances the stickiness of commercial bank customers; thirdly, optimizing the internal operating procedures of commercial banks and improving the efficiency of internal collaboration of commercial banks are conducive to the development of commercial banks' cost reduction and efficiency enhancement work, and ultimately to improve commercial banks Lay a solid foundation for profitability.

Based on the specific methods and practical experience of domestic and foreign commercial banks implementing technology finance strategies, the author suggests that commercial banks should clarify the development path of technology finance, strengthen the application efficiency of technology finance, and accelerate the talent pool of technology finance, so as to realize the top-level design and technology of technology finance. The high degree of matching of financial execution plans realizes the in-depth integration of technological financial technology tools with commercial bank financial services, and realizes the seamless 
connection between technological financial technology research and development and commercial banking financial business applications, so as to truly ensure technology at the business level, operation level, and management level. The efficient empowerment of financial tools on the operation and management of commercial banks truly enhances the core competitiveness of commercial banks, thereby increasing the profitability of commercial banks, and ultimately promoting the efficient, stable and sustainable development of commercial banks.

\section{Conflicts of Interest}

The author declares no conflicts of interest regarding the publication of this paper.

\section{References}

Chen, J. X., \& Sun, Y. J. (2019). The Impact of Internet Finance on the Profitability of Commercial Banks: A Segmented Study based on Internet Technology and Information Service Indicators. Electronic Commerce, No. 8, 50-52.

Lai, B. H. (2018). Research on the Profitability of My Country's Large State-Owned Commercial Banks: From the Perspective of DuPont Analysis. Journal of Minnan Normal University (Philosophy and Social Sciences Edition), 32, 1-6.

Lu, M. (2020). Research on the Strategy of Commercial Banks to Improve Profitability from the Perspective of Science and Technology Finance. Journal of Chifeng University (Natural Science Edition), 36, 72-74.

Wang, Q. S. (2020). An Empirical Study on the Impact of Interest Rate Marketization on the Profitability of Commercial Banks. China Business Forum, No. 14, 35-37.

Wang, X. Y. (2017). An Empirical Analysis of the Factors Influencing the Profitability of My Country's Five Major Commercial Banks. Modern Economic Information, 13, 249-250.

Wang, X., Wang, X. B., \& Bai, Z. Q. (2020). Research on the Inverted U-Shaped Relationship between the Loan-to-Deposit Ratio and the Profitability of Commercial Banks: Introducing the Intermediary Effect Model of Non-Performing Loan Rate. Scientific Research Management, 41, 230-238.

Wu, S. H. (2020). Research on the Implementation Path of Commercial Banks' Profitability Improvement from the Perspective of Science and Technology Finance. Business Economics, No. 1, 184-185.

You, X. C. (2020). Research on the Factors Influencing the Profitability of My Country's Joint-Stock Commercial Banks. Modern Finance, No. 2, 33-37.

Yu, B., \& Zhang, H. N. (2017). Research on the Influencing Factors of the Profitability of My Country's Commercial Banks. North China Finance, No. 7, 44-48.

Zhang, S. (2020). Research on the Impact of Green Credit on the Profitability of Commercial Banks. Green Finance and Accounting, No. 3, 3-5.

Zhang, Y. L. (2017). On the Impact of Economic Cycle Strategy on the Profitability of Commercial Banks. Modern Economic Information, No. 18, 291.

Zhang, Y. Y. (2013). Regional Analysis of Factors Affecting the Profitability of My Country's Commercial Banks. Statistics and Decision, No. 16, 151-153. 